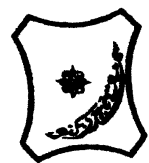

Bayero Journal of Pure and Applied Sciences, 9(1): 99 - 107

Received: February, 2016

Accepted: April, 2016

ISSN $2006-6996$

\title{
EFFECTS OF MICRONUTRIENTS ON OXIDATIVE STRESS IN HIV POSITIVE PATIENTS TAKING HIGHLY ACTIVE ANTIRETROVIRAL THERAPY (HAART) IN A TERTIARY HEALTH CARE FACILITY IN KANO, NORTHWEST NIGERIA
}

\author{
$*^{1}{ }^{3}$ Jibril, M. M., ${ }^{2}$ Igbiks, T., ${ }^{3}$ Atta, A. O., ${ }^{4}$ Attah, C. 0. ${ }^{1}$ Imam, A. A., ${ }^{1}$ Muhammad, Y. Y., ${ }^{1}$ Bala, \\ M., and ${ }^{1}$ Abubakar, $\mathrm{H}$. \\ ${ }^{1}$ Department of Biochemistry, Bayero University, Kano, Nigeria. \\ ${ }^{2}$ Department of Pharmacology, Aminu Kano Teaching Hospital, Kano, Nigeria. \\ ${ }^{3}$ UNICEF Bauchi Field Office, Bauchi, Nigeria. \\ ${ }^{4}$ Chemistry Department, Federal College of Education, Kano, Nigeria. \\ *Corresponding author. mmjibril.bch@buk.edu.ng P.M.B.3011, Kano-Nigeria. +2347033971799, +60103104799
}

\section{ABSTRACT}

The study examined the effects of micronutrients supplementation on oxidative stress markers in HIV positive patients on highly active antiretroviral therapy (HAART), attending Aminu Kano Teaching Hospital (AKTH) Kano-Nigeria. Fifty four (54) HIV positive individuals already taking HAART were placed on a daily dose of a multivitamin supplement for a period of three months. Another 54 HIV positive subjects who were already on HAART served as the control group for the same period of time. Prior to the multivitamin supplementation, the baseline mean serum vitamin $A, C$, and $E$, selenium, zinc, malondehaldehyde (MDA), albumin, total protein, and CD4+ count values were established. With the exception of mean serum vitamin $C$, the mean serum values for the studied parameters after the supplementation period increased significant/y $(P<0.05)$ in the non supplemented group compared to their baseline values. The mean serum vitamin $A, C$, and $E$, Se, total protein and CD4+ count of the supplemented group increased significantly when compared to their baseline values. Mean serum MDA was significantly decreased $(P<0.05)$ in the multivitamin supplemented group compared to their baseline. No significant difference $(P<0.05)$ was seen in the mean serum vitamin $C$ and albumin of the multivitamin supplemented group as compared to their baseline. The mean serum vitamins $A, C$, and $E$ and the CD4+ count of the multivitamins supplemented subjects significantly increased $(P<0.05)$ when compared to that of the non supplemented subjects. Mean serum selenium and zinc increased significantly $(P<0.05)$ in the non supplemented subjects but not in the supplemented subjects. The serum thiobarbituric acid reactive substances (TBARs) in the form of malondialdehyde (MDA), for the supplemented subjects was found to reduce significantly $(P<0.05)$ compared to that of the non supplemented subjects. Statistical analysis showed no significant difference between the supplemented and the non supplemented subjects in their serum total protein and albumin. Among the supplemented Subjects, vitamin $A$ and $C$ increased significantly $(P<0.05)$ in the ARV treatment naïve sub group. Vitamin $E$, selenium and zinc increased significantly $(P<0.05)$ in the ARV treated sub group, while MDA decreased significantly $(P<0.05)$ in this sub group. Micronutrient supplementation was therefore shown to reduce oxidative stress in HIV positive patients on HAART and could possibly be very helpful as an adjunct in the treatment of this disease.

Key Words: Antiretroviral, micronutrients, malondialdehyde, ART naïve, reactive oxygen species, supplementation.

\section{INTRODUCTION}

HIV infection is associated with increased reactive oxygen species (ROS) production and increased utilisation of antioxidants, leading to oxidative stress (Baruchel, and Wainberg, 1992; Ngondi et al., 2006). Oxidative stress is a condition which arises when the production of free radicals exceeds the body's ability to neutralise and eliminate them. In healthy body, ROS and antioxidants remain in balance. When the balance is disrupted towards an over abundance of ROS, oxidative stress occurs (Agarwal et al., 2005). Oxidative stress is a known cofactor of HIV progression to AIDS (Ngondi et al., 2006). The discovery of HIV resulted in a broadening of the hypothesis that oxidative stress is a principal mechanism in both the development of AIDS and expression of HIV (Papadopulos-Eleopulos, 1988; Papadopulos-Eleopulos et al., 1989).

It has been proposed that oxidative stress is the common mediator of apoptotic cell death in AIDS. In populations of HIV-infected patients treated with HAART, the role of oxidative stress in disease progression has become more complicated. Whereas HIV itself increases oxidative stress levels through replication, control of the virus with antiretroviral therapy may not, as one might expect, reduce oxidative stress levels, as the medications themselves may increase oxidative stress (Tang et al., 2005). 
Micronutrient supplements have been proposed as a low-cost immunomodulating intervention that may slow the progression of HIV disease to AIDS (Semba and Tang 1999; Fawzi, 2003). If efficacious, supplements could delay the onset of advanced disease and the need for ART, saving ARVs for when they are needed most, and reducing drug related adverse events and cost. Micronutrients are essential for maintaining proper immunologic function (Scrimshaw and SanGiovanni, 1997; CunninghamRundles et al., 2005). When used as an adjunct to HAART may reduce oxidative stress and improve immune reconstitution. (Drain et al., 2007).

In HIV infected persons, low serum concentration of vitamins and minerals, termed micronutrients, are associated with an increased risk of HIV disease progression and mortality. A small number of observational studies suggested that some, micronutrients may be repleted after HAART initiation, and few intervention studies found that certain micronutrients may be a beneficial adjunct to HAART (Drain et al., 2007). The present universal access to HAART has prompted the need for a better understanding of the role of micronutrient deficiencies and the role of micronutrient supplements in HIVpositive persons receiving HAART. There has been little prior experience with extensive use of micronutrients in African populations, and long-term multivitamin administrations have not been considered sustainable. Moreover, there are no solid data regarding the value of multivitamins among HIVinfected adults in the industrialised world, although routine supplementation is often practiced (Marson and De Cock, 2004).

Thus there is the need to unravel the role of micronutrients supplementation (nutrition), in the public health response to HIV and AIDS infection in Africa, in this era of increasing access to antiretroviral therapy. Accordingly, this study was aimed at determining the effect of micronutrients supplementation on HIV positive patients receiving HAART and how the supplementation affects oxidative stress.

\section{MATERIALS AND METHODS Patients under the Study}

This study was conducted according to the guidelines laid down in the Declaration of Helsinki and all procedures involving patients were approved by the Medical Advisory Committee (MAC) of Aminu Kano Teaching Hospital (AKTH). Written informed consent was received from all patients. Eligible patients were HIV seropositive, above the age of 13 , non pregnant women, and either on HAART or positive living. HIV positive outpatients (108) were recruited into the study in Professor S.S. Wali Virology Center of AKTH. A scanned copy of the MAC approval is attached to this manuscript.

\section{Sample Collection}

Patients were randomly divided into two equal groups of 54 subjects each. One group was placed on daily dose of a multivitamin; each of these patients was given a daily dose (one tablet daily) of a multivitamin containing $500 \mathrm{IU}$ vitamin A, $150 \mathrm{mg}$ vitamin C, $25 \mathrm{mg}$ vitamin $E$, 200mg selenium, $15 \mathrm{mg}$ zinc and other component vitamins and minerals for a period of three months. The other group was taken as the control.

Venous blood $(10 \mathrm{ml})$ was collected from all patients and divided into heparinised and Ethylene Diamine Tetra Acetate (EDTA) tubes. After centrifugation, at 3000 revolution per minute (rpm) for 10 minutes, the respective sera were collected into clean tubes and stored under $-20^{\circ} \mathrm{C}$. Samples of the heparinised sera were set aside for the measurement of serum total proteins and albumin, while the sera containing EDTA were set aside for the determination of malondialdehyde (MDA). The baseline values of these parameters were assayed within four weeks of sample collection. Analysis of the baseline parameters were repeated after the multivitamin supplementation period.

\section{Biochemical Analysis}

Serum albumin was determined using a commercially available Dye Binding method kit (Pinnell and Northam, 1978), serum total protein was determined by the commercially available Biuret method kit (Gomall, 1949), while serum lipid peroxidation was determined by the Thiobarbituric acid method as described by Okhawa, Ohishi, and Yagi, (1979). Serum vitamin A was determined by the method of Bessay, Lowry, Brock, and Lopez, (1946), serum vitamin $C$ was determined by the method of Roe and Kuether, (1943). While serum vitamin $E$ was determined by the method of Fabianek, Defillipi, Richards, and Herp, (1967). Determination of serum Zinc and Selenium was done by the Atomic Absorption Spectrophotometry (AAS) method described by Kenako (1999) while Serum Malondialdehyde was determinedthe method described by Okhawa et al., (1979).

\section{Statistical Analysis}

Values are expressed as mean \pm standard error of mean (SEM). Data was analyzed by ANOVA, paired sample and two samples $T$ - test using the SPSS statistical package, including the multiple comparison test. A P value $<0.05$ is considered significant.

\section{RESULTS}

The result in Table 1 shows significant increase $(P<0.05)$ in the mean serum vitamin $A$ and $E$, selenium and zinc of the non supplemented patients, when compared to that of their corresponding baseline values. The MDA, albumin, total proteins and CD4+ count of the non supplemented subjects increased significantly $(P<0.05)$ compared to those of their corresponding baseline. 
Table 1: Mean serum vitamin A, C, and E, Se, Zn, MDA, albumin, and total protein values for nonsupplemented patients and that of their baseline.

$\begin{array}{clllllllll}\text { Groups } & \text { Vit.A } & \text { Vit.C } & \text { Vit.E } & \text { Se } & \text { Zn } & \text { MDA } & \text { ALB } & \text { TP } & \text { CD4+ count } \\ & (\mu g / d l) & (\mathrm{mg} / \mathrm{dl}) & (\mu \mathrm{g} / \mathrm{dl}) & (\mu \mathrm{g} / \mathrm{dl}) & (\mu \mathrm{g} / \mathrm{dl}) & (\mu \mathrm{mol} /) & (\mathrm{g} / \mathrm{dl}) & (\mathrm{g} / \mathrm{dl}) & \left(\mathrm{cells} / \mathrm{mm}^{3}\right)\end{array}$

\begin{tabular}{llllllllll}
\hline Baseline & $24.96^{\mathrm{a}}$ & 0.42 & $0.20^{\mathrm{b}}$ & $22.33^{\mathrm{c}}$ & $58.16^{\mathrm{d}}$ & $7.92^{\mathrm{e}}$ & $2.35^{\mathrm{f}}$ & $2.76^{\mathrm{g}}$ & $269.81^{\mathrm{h}}$ \\
$\mathrm{n}=54$ & \pm & \pm & \pm & \pm & \pm & \pm & \pm & \pm & \pm \\
& 0.82 & 0.01 & 0.00 & 0.04 & 0.19 & 0.08 & 0.19 & 0.02 & 2.73 \\
& & & & & & & & & \\
& & & & & & & & \\
Non & $35.33^{\mathrm{a}}$ & 0.71 & $1.38^{\mathrm{b}}$ & $25.63^{\mathrm{c}}$ & $66.30^{\mathrm{d}}$ & $9.97^{\mathrm{e}}$ & $3.27^{\mathrm{f}}$ & $7.49^{\mathrm{g}}$ & $296.00^{\mathrm{h}}$ \\
Supplemented & \pm & \pm & \pm & \pm & \pm & \pm & \pm & \pm & \pm \\
$\mathrm{n}=54$ & 1.24 & 0.01 & 0.01 & 0.12 & 0.22 & 0.09 & 0.01 & 0.03 & 2.78
\end{tabular}

Values are mean \pm S.E. of mean. $n=$ number of subjects $=5$ Values in the same column having the same superscript have significant difference at $\mathrm{P}<0.05$

Data in Table 2 indicates significant increase $(P<0.05)$ in the mean serum vitamin $A, C$ and $E$ of the multivitamins supplemented patients, compared with their corresponding baseline values. There was also significant increase $(P<0.05)$ in the mean serum selenium of the supplemented patients compared to that of their corresponding baseline. No significant difference was observed in the mean serum zinc of the supplemented patients as compared to their corresponding base line. When compared with that of their baseline, the mean serum MDA of the multivitamins supplemented subjects was found to have decreased significantly $(P<0.05)$. Significant $(P<0.05)$ difference was also observed in the mean serum total proteins of the multivitamins supplemented subjects when compared to that of their corresponding baseline. No significant difference was observed in the mean serum albumin of multivitamins supplemented subjects compared to that of their corresponding baseline.

Table 2: Mean serum vitamin A, C, and E, Se, Zn, MDA, albumin, and total protein values for multivitamins supplemented patients and that of their baseline.

\begin{tabular}{|c|c|c|c|c|c|c|c|c|c|}
\hline Groups & $\begin{array}{l}\text { Vit. A } \\
\text { ( } \mu g / d l \\
\text { ) }\end{array}$ & $\begin{array}{l}\text { Vit. C } \\
(\mathrm{mg} / \mathrm{dl} \\
\text { ) }\end{array}$ & $\begin{array}{l}\text { Vit. E } \\
(\mu g / d \mathrm{dl} \\
)^{\prime}\end{array}$ & $\begin{array}{c}\text { Se } \\
(\mu \mathrm{g} / \mathrm{dl} \\
)^{-}\end{array}$ & )$^{\begin{array}{c}Z n \\
(\mu g / d l\end{array}}$ & $\begin{array}{l}\text { MDA } \\
(\mu \mathrm{mol} / \mathrm{dl} \\
)\end{array}$ & $\begin{array}{l}\text { ALB } \\
(g / d l \\
)^{2}\end{array}$ & $\begin{array}{l}\text { TP } \\
(\mathrm{g} / \mathrm{dl} \\
)^{-}\end{array}$ & $\begin{array}{l}\text { CD4+ } \\
\text { count } \\
\text { (cells } / \mathrm{mm}^{3} \\
\text { ) }\end{array}$ \\
\hline $\begin{array}{l}\text { Baseline } \\
n=54\end{array}$ & $\begin{array}{l}21.46^{a} \\
\pm \\
0.31\end{array}$ & $\begin{array}{l}0.47^{b} \\
\pm \\
0.01\end{array}$ & $\begin{array}{l}0.17^{\mathrm{C}} \\
\pm \\
0.00\end{array}$ & $\begin{array}{l}22.61^{d} \\
\pm \\
0.06\end{array}$ & $\begin{array}{l}65.07 \\
\pm \\
0.16\end{array}$ & $\begin{array}{l}14.78^{\mathrm{e}} \\
\pm \\
0.06\end{array}$ & $\begin{array}{l}2.87 \\
\pm \\
0.02\end{array}$ & $\begin{array}{l}3.24^{f} \\
\pm \\
0.04\end{array}$ & $\begin{array}{l}321.96^{9} \\
\pm \\
3.72\end{array}$ \\
\hline $\begin{array}{l}\text { Supplemente } \\
\text { d } n=54\end{array}$ & $\begin{array}{l}41.40^{a} \\
\pm \\
0.62\end{array}$ & $\begin{array}{l}4.22^{b} \\
\pm \\
0.07\end{array}$ & $\begin{array}{l}6.91^{c} \\
\pm \\
0.00\end{array}$ & $\begin{array}{l}23.99^{d} \\
\pm \\
0.06\end{array}$ & $\begin{array}{l}64.78 \\
\pm \\
0.24\end{array}$ & $\begin{array}{l}0.89^{\mathrm{e}} \\
\pm \\
0.02\end{array}$ & $\begin{array}{l}3.14 \\
\pm \\
0.16\end{array}$ & $\begin{array}{l}7.79^{f} \\
\pm \\
0.03\end{array}$ & $\begin{array}{l}442.74^{9} \\
\pm \\
3.53\end{array}$ \\
\hline
\end{tabular}

Values are mean \pm standard error (S.E) of mean. $n=$ number of subjects $=5$ Values in the same column having the same superscript have significant difference at $\mathrm{P}<0.05$.

In Table 3 , significant increase $(P<0.05)$ was observed in the mean serum vitamins $A, C$ and $E$, and the CD4+ count of the supplemented group when compared to those of the non supplemented subjects. The mean serum selenium and zinc of the non supplemented patients was found to be significantly increased $(P<0.05)$ than the values obtained for the multivitamin supplemented patients. The MDA was significantly lower $(P<0.05)$ in the multivitamins supplemented patients compared to that of the non supplemented patients. The serum total proteins of the multivitamins supplemented subjects was slightly above that of the control subjects, but no significant difference was observed between the mean serum total proteins and albumin of the two groups. 
Table 3: Mean serum Vitamin A, C and E, Se, Zn, MDA, albumin, and total proteins values of multivitamins supplemented and non supplemented patients.

\begin{tabular}{llllllllll}
\hline Groups & Vit.A & Vit.C & Vit.E & Se & Zn & MDA & ALB & TP & CD4+ count \\
& $(\mu \mathrm{g} / \mathrm{dl})$ & $(\mathrm{mg} / \mathrm{dl})$ & $(\mu \mathrm{g} / \mathrm{dl})$ & $(\mu \mathrm{g} / \mathrm{dl})$ & $(\mu \mathrm{g} / \mathrm{dl})$ & $(\mu \mathrm{mol} /)$ & $(\mathrm{g} / \mathrm{dl})$ & $(\mathrm{g} / \mathrm{dl})$ & $\left(\mathrm{cells} / \mathrm{mm}^{3}\right)$
\end{tabular}

\begin{tabular}{llllllllll}
\hline Non & $35.33^{\mathrm{a}}$ & $0.71^{\mathrm{b}}$ & $1.38^{\mathrm{c}}$ & $25.63^{\mathrm{d}}$ & $66.30^{\mathrm{e}}$ & $9.97^{\mathrm{f}}$ & 3.27 & 7.49 & $296.00^{\mathrm{g}}$ \\
supplemented & \pm & \pm & \pm & \pm & \pm & \pm & \pm & \pm & \pm \\
$\mathrm{n}=54$ & 1.24 & 0.01 & 0.01 & 0.12 & 0.22 & 0.09 & 0.01 & 0.03 & 2.78 \\
& & & & & & & & & \\
& & & & & & & & & \\
Supplemented & $41.40^{\mathrm{a}}$ & $4.22^{\mathrm{b}}$ & $6.91^{\mathrm{c}}$ & $23.99^{\mathrm{d}}$ & $64.98^{\mathrm{e}}$ & $0.89^{\mathrm{f}}$ & 3.14 & 7.79 & $442.74^{\mathrm{g}}$ \\
$\mathrm{n}=54$ & \pm & \pm & \pm & \pm & \pm & \pm & \pm & \pm & \pm \\
& 0.62 & 0.07 & 0.12 & 0.15 & 0.24 & 0.02 & 0.16 & 0.03 & 3.53
\end{tabular}

Values are mean \pm standard error (S.E) of mean. $n=$ number of subjects $=5$ Values in the same column having the same superscript have significant difference at $P<0.05$.

The result in Table 4 indicates significant $(P<0.05)$ increase in the mean serum vitamin $A$ of the multivitamins supplemented ARV naive group compared to that of the multivitamin supplemented ARV treated group. Mean serum selenium and zinc significantly increased in the supplemented ARV treated group, while between the two groups, no significant difference $(P>0.05)$ was observed in their mean serum vitamin $\mathrm{C}$ and $\mathrm{E}, \mathrm{MDA}$ and $\mathrm{CD} 4+$ count.

Table 4: Mean serum vitamins A, $C$ and $E$, Se, Zn, MDA and CD4+ count values for ARV treated and ARV naive patients who benefited from multivitamin supplementation.

\begin{tabular}{|c|c|c|c|c|c|c|c|}
\hline Groups & $\begin{array}{l}\text { Vitamin } \\
\text { A } \\
(\mu g / d l)\end{array}$ & $\begin{array}{l}\text { Vitamin C } \\
\text { (mg/dl) }\end{array}$ & $\begin{array}{l}\text { Vitamin E } \\
(\mu \mathrm{g} / \mathrm{dl})\end{array}$ & $\begin{array}{l}\text { Selenium } \\
(\mu g / d \mathrm{l})\end{array}$ & $\begin{array}{l}\text { Zinc } \\
(\mu g / d I)\end{array}$ & $\begin{array}{l}\text { MDA } \\
(\mu \mathrm{mol} / \mathrm{L})\end{array}$ & $\begin{array}{l}\text { CD4+ count } \\
\left(\text { cells } / \mathrm{mm}^{3}\right)\end{array}$ \\
\hline $\begin{array}{l}\text { Supplemented } \\
\text { ARV naïve } \\
\text { group }(n=11)\end{array}$ & $\begin{array}{c}44.55^{\mathrm{a}} \\
\pm \\
8.98\end{array}$ & $\begin{array}{l}4.57 \\
\pm \\
1.25\end{array}$ & $\begin{array}{l}6.88 \\
\pm \\
2.19\end{array}$ & $\begin{array}{l}21.71^{\mathrm{b}} \\
\pm \\
0.38\end{array}$ & $\begin{array}{l}61.02^{\mathrm{C}} \\
\pm \\
3.77\end{array}$ & $\begin{array}{l}0.89 \\
\pm \\
0.23\end{array}$ & $\begin{array}{l}430.7 \\
\pm \\
81.2\end{array}$ \\
\hline $\begin{array}{l}\text { Supplemented } \\
\text { ARV treated } \\
\text { group }(n=44)\end{array}$ & $\begin{array}{l}41.61^{\mathrm{a}} \\
\pm \\
4.96\end{array}$ & $\begin{array}{l}4.08 \\
\pm \\
0.48\end{array}$ & $\begin{array}{l}7.29 \\
\pm \\
0.95\end{array}$ & $\begin{array}{l}24.44^{\mathrm{b}} \\
\pm \\
1.27\end{array}$ & $\begin{array}{l}64.76^{c} \\
\pm \\
1.81\end{array}$ & $\begin{array}{l}0.81 \\
\pm \\
0.13\end{array}$ & $\begin{array}{l}442.74 \\
\pm \\
3.53\end{array}$ \\
\hline
\end{tabular}

Values are mean \pm standard error of mean (SEM). $n=$ number of subjects $=5$. Values in the same column having the same super script are significantly different at $\mathrm{P}<0.05$.

\section{DISCUSSION}

Among the non supplemented patients, the mean serum levels of vitamin $A$ and $E$, Se, $\mathrm{Zn}$, albumin, total protein and $\mathrm{CD} 4+$ count at the end of the multivitamin supplementation period, were found to have increased significantly $(P<0.05)$ when compared with their corresponding baseline values (Table 2). This increase may be as a result of increase in the dietary intake of these vitamins and minerals. It could also be due to the HAART regimens the patients were placed on. The non supplemented subjects were well educated on the importance of taking dietary sources of micronutrients, which they actually adhered to. Some micronutrients, vitamin $\mathrm{A}$ and $\mathrm{E}$, and selenium have been documented to increase in HIV patients taking HAART especially those whose regimen includes protease inhibitors (PI) (Rousseau et al., 2000). Tang et al., (2000) have also documented increase in serum levels of vitamin $\mathrm{E}$, beta carotene, and beta cryptoxanthin among HIV positive injection drug users (IDUs) on PI based HAART, than among HIV positive IDUs taking non HAART regimens.

The increase in the mean serum total protein and CD4+ count seen in the non supplemented subjects might be due to the continued HAART medication by the patients. HAART medication have been reported to reconstitute the immune system and repair the damages already caused by the HIV virus (www.overt.org) and increase the CD4+ count as well as reduce the viral load of the patient. A slight increase in the mean serum albumin of the non supplemented patient compared with their corresponding baseline values is evident, but does not produce a significant difference $(P>0.05)$. This might be due to the fact that people living with HIV (PLWH) have increased energy expenditure, leading to HIV related weight loss (Batterham, 2005). Studies have found that relatively small weight loss (between $5 \%$ and $10 \%$ over six months) is quite common among PLWH who are taking treatment and not trying to lose weight (Tang et al., 2005). 
No significant difference was observed in the mean serum vitamin, $\mathrm{C}$ of the non supplemented patients as compared with their baseline value. This is in line with most scientific findings on vitamin $\mathrm{C}$ level in HIV disease. Vitamin $C$ has been reported to be rapidly consumed by cells in state of pathology compared with normal cells (Cathcart, 1984). It is also paralleled by the significant increase $(P<0.05)$ in the mean MDA level of the non supplemented patients, when compared with that of the baseline.

The increase in MDA level (Table 3 ) indicates an increase in the level of lipid peroxidation in the non supplemented patients. This explains the increase in oxidative stress in these patients, which might be as a result of the HAART medication, complementing the pre-existing oxidative stress already caused by the HIV itself. HIV infection increases the oxidative stress process, which is further increased by the use of antiretroviral therapy (ART) (Ngondi et al., 2006). This is evidenced by a significantly higher MDA in the non supplemented subjects.

Other studies have reported that HAART medication may increase oxidative stress levels above and beyond levels caused by virus itself. In HIV infection, reactive oxygen species may enhance viral replication by activating nuclear transcription factors which ultimately lead to viral gene expression. In addition, Zidovudin was shown to promote oxidative damages to DNA in HIV infected adults, a process that was reversible with vitamin $\mathrm{C}$ and vitamin $\mathrm{E}$ supplementation (Allard et al., 1998).

It has been observed that, HAART may induce (i) an increase in oxidant generation (ii) a decrease in anti oxidant protection or (iii) a failure to repair oxidative damage (Ngondi et al., 2006). This is obviously seen in the result presented in table 2 , by the increase in serum level of MDA in the non supplemented subjects after a period of three months. Oxidative stress mediated cell damage occurs in part, via reactive oxygen species (ROS), ROS include molecules like $\mathrm{H}_{2} \mathrm{O}_{2}$, ions like hypochloride ions; radicals like the hydroxyl radical; and superoxide anion, which is both ion and radical. (Ngondi et al., 2006).

These observations also indicated that multivitamins supplementation increased the serum concentrations of vitamins $A, C$ and $E$ and selenium, but not mean serum zinc in the supplemented subjects as compared with that of their corresponding baseline. The physiological roles of the multivitamins must have contributed to this significant outcome. Vitamin A increases lymphocyte response (Semba, 1999); Vitamin $C$ increases cell mediated immune response and reduces reverse transcriptase activity (Benedich, 1988; Harakeh et al.,1990); vitamin E increases T cell-mediated function and lymphocyte proliferation (Meydani et al., 1995). It also reduces nuclear transcription factor XB (NF-XB) concentrations and the reduction of oxidant compounds (Packer, 1993; Packer, and Suzuki, 1993). Selenium is needed for the proper functioning of neutrophils and T- lymphocytes (Ferencik, and Ebringer, 2003).

Zinc plays specific roles as antioxidant, immune modulator (Tanaka et al.,1990), and possible direct antiviral activity (Favier et al., 1994; Spriestma,1999).
Zinc in vitro, has been found to inhibit cell death by tumour necrosis factor (TNF), a cytokine linked to cellular apoptosis and wasting syndrome in HIV (Fleiger et al., 1989). Increase in serum vitamin A, C, and $\mathrm{E}$ were also reported by (Jaruga et al., 2002). A study by Burbano et al., (2002), also reported increase in serum level of selenium in HIV positive patients after two year supplementation with selenium.

Though no significant difference was observed, the slight decrease in serum level of zinc seen in the supplemented patients compared with the baseline value (Table 2) might be due to the increase in the hepatic zinc intake. As hepatic zinc up take increases, zinc level decreases reflecting zinc role as acute phase reactant (Scrinivas et al., 1988). Since zinc plays a role in acute infection and its subsequent altered metabolism in chronic infection, it has been argued that serum levels may not be an accurate reflection of immune impairment related to zinc body stores and zinc availability in HIV (Mocchegiani et al., 1992). Zinc has both enhancing and inhibiting activities depending on the concentration of zinc in the surrounding tissues (Larsen and Auld, 1991). This decrease may also be due to the rapid binding of zinc ions to HIV protease (an enzyme responsible for cutting of viral peptide chain to form new infectious viral particles) making it inactive, thereby preventing the production and proliferation of new HIV viruses. Multiple studies have shown if sufficient zinc ions are bound to the protease enzyme, it remains inactive (Zhang et al., 1991). The low serum level of zinc in the supplemented subjects might also be due to the inclusion of zidovudin (AZT) in the HAART regimen of up to $90 \%$ of the supplemented patients. AZT metabolism necessitates a zinc dependent thymidin kinase for conversion to its active forms, which could lead to decrease in effectiveness of the drug in zinc deficient patients (Baum et al., 1991). Triple antiviral therapy have been found to improve zinc absorption and serum zinc levels due to improved zinc absorption as a result of the anti inflammatory effect on the gut (Mocchegiani et al., 1999)

Mean serum albumin slightly increase in the supplemented subjects but with no significant difference $(P>0.05)$ when compared to their corresponding baseline value. This might be due to increased appetite that resulted from the micronutrient supplementation, thereby causing the patients to eat regularly. Malondialdehyde (MDA), a lipid peroxidation marker is greatly reduced in the supplemented subjects compared with that of the baseline. This may be a consequence of the combined effects conferred by the physiological role of the micronutrients vitamin $A, C$, and $E$, selenium and zinc. Several studies have shown the relationships between micronutrients and oxidative stress. One randomized placebo- controlled trial shows that a daily supplementation with vitamins $A, C$ and $E$ for a period of three months reduced oxidative stress level (Cathcart, 1984). A six month placebo controlled trial study of daily supplementation with vitamins A, C and $E$ also recorded a reduced oxidative stress in the supplemented HIV subjects (Jaruga et al., 2002). 
Serum total proteins and CD4+ count also increased in the supplemented subjects when compared to their corresponding baseline. This might also be due to the combined effect of physiologic, hematologic and clinical roles played by the antioxidant vitamins $A, C$ and $E$ including selenium and zinc. Increase in these parameters in the body of HIV positive individuals have been reported as indices for improvement in their health status, especially HIV positive pregnant women and neonates, through reduction in clinical HIV disease progression and HIV related mortality (Fawzi et al., 1998; Mocchegiani et al., 1999; Jiamton et al., 2003; Chaisilwattana et al., 2003). Jaruga et al., (2002) also reported increased CD4+ count in a population of HIV positive patients taking HAART after multivitamin supplementation for a period of six months.

This study is also in line with previous reports on the repletion of micronutrients deficiency, and reduced oxidative stress in HIV disease conditions by micronutrients supplementation (Allard et al., 1998; Batterham et al., 2001; Burbano et al., 2002; Jaruga et al., 2002). This is seen in the increased mean serum levels of vitamins $A, C$, and $E$ in the supplemented subjects when compared with the non supplemented subjects. This increased mean serum level of vitamin $A, C$ and $E$ is justified by the reduced serum MDA, as compared with the values for the non supplemented subjects.

The serum increase in the antioxidant vitamins $A, C$ and $\mathrm{E}$ indicates improvement in the antioxidant

\section{REFERENCES}

Agarwal, A., Gupta, S., Sharma, R. K. (2005). Role of oxidative stress in female reproduction. $J$ Repro Biol Endocrino/ 3:28.

Allard, J. P., Aghdassi, E., Chau, J., Tam, C., and Kovacs, C. M., and Salit, I. E. (1998). Effects of vitamin $\mathrm{E}$ and $\mathrm{C}$ supplementation on oxidative stress and viral load in HIV-infected subjects. AIDS12:1653-1659. Available at www.overt.org Retrieved 5/9/2009.

Baruchel, S. and Wainberg, M. A. (1992). The role of oxidative stress in disease progression in individuals infected by the human immunodeficiency virus. (Rev). Journal Leucocyte Biology 52:111-114.

Batterham, M. J. (2005). "Investigating heterogeneity in studies of resting energy expenditure in persons with HIV/AIDS:a meta-analysis". American Journal of Clinical Nutrition 81(3).

Batterham, M., Gold, J., and Naidoo, D. (2001) A preliminary open label dose comparison using an antioxidant regimen to determine the effect on viral load and oxidative stress in men with HIV/AIDS. Eur J Clin Nutr 55:107-14.

Baum, M. K., Javia, J. J., and Mantero-Atienza, E. (1991). Zidovudin-associated adverse reactions in a longitudinal study asymptomatic HIV-1 homosexual males. J. Acquir Immune Defic Syndr 4:1218-1226. defense system of the supplemented subjects. This subsequently causes reduced lipid peroxidation and scavenging the serum MDA, thereby drastically reducing oxidative stress in the supplemented subjects. The reduced oxidative stress also caused a reduction in the survival condition for the virus (since HIV virus survives well in the presence of free radicals), thereby reconstituting the immune system. ( Allard et al., 1998).

The study also reported no significant $(P>0.05)$ difference between the mean serum albumin and total protein of the supplemented subjects and the non supplemented subjects. This might be as a result of HAART medication, HAART medications have been found to restore the immune constitution (www.overt.org). A slight increase was observed in the mean serum total proteins of the supplemented subjects compared with that of their non supplemented counterparts but, with no significant difference $(P>0.05)$. This might be due to the multivitamins supplementation; multivitamin supplements are known to increase appetite, which can in turn boost the immune system by causing increase in the immunoglobulins.

\section{CONCLUSION}

Micronutrients supplementation reduces oxidative stress in HIV positive patients on ART and ARV naïve patients attending virology clinic in AKTH in KanoNigeria and improves the clinical outcomes of the disease conditions.

Benedich, A. (1988). Antioxidant vitamins and immune responses. In: Chandra RK, ed. Nutrition and immunology. New York, NY: Alan R Liss, Inc: $125-47$.

Bessay, O. A., Lowry, O. H., Brock, M. J., and Lopez, J. A. (1946). The determination of vitamine $A$ and carotene in small quantities of blood serum. J. Biol. Chem. 166:177.

Burbano, X., Miguez-Burbano, M. J., McCollister, K., Zhang, G., Rodriguez, A. and Ruiz, P. (2002) Impact of a selenium chemoprevention clinical trial on hospital admissions of HIV-infected participants. HIV Clin Trials 3:483-491. Scrinivas, U., Braconier, H. and Jeppsson, M. (1988). Trace element alterations in infectious diseases. Scand J Clin Lab Invest 48:495-500.

Cathcart, R. F. (1984). Vitamin C in the Treatment of Acquired Immune Deficiency Syndrome (AIDS) Medical Hypothesis, 14 (4): 423-433.

Cunningham-Rundles, S., McNeeley, D. F., and Moon, A. (2005). Mechanism of nutrient modulation of the immune response. $J$ Allergy Clin Immuno/ 115:1119-28.

Drain, P. K., Roland, Kuta., Ferdinand, M., and Wafaie W. Fawzi. (2007). Micronutrients in HIVpositive persons receiving highly active antiretroviral therapy. (Rev). American Journal of Clinical Nutrition. 85 (2) 333-345. 
Fabianek, J., Defillipi, J., Richards, T., and Herp, A. (1967). Micro method For Tocopherol Determination in Blood serum. American Association for Advancement of Science, Washington D.C

Favier, A., Sappey, C., and Leclere, P. (1994). Antioxidand status and lipid peroxidation in patients infected with HIV. Chm Biol interact 91:165-180.

Fawzi, W. W. (2003). Micronutrients and human immunodeficiency virus type 1 disease progression among adults and children. Clin Infect Dis 37(Suppl 2):S112-S116.

Fawzi, W. W., Msamanga, G. I., Spiegelman, D., Urassa, E. J. N., McGrath, N., Mwakagile, D. (1998). For the Tanzania Vitamin and HIV Infection Trial Team. Randomised trial of effects of vitamin supplements on pregnancy outcomes and $\mathrm{T}$ cell counts in HIV-1-infected women in Tanzania. Lancet 351:1477-1482.

Fawzi, W. W., Msamanga, G. I., Spiegelman, D., Wei, R., Kapiga, S., Villamor, E., Mwakagile, D., Mugusi, F., and Hertzmark, E. (2004) A randomized trial of multivitamin supplements and HIV disease progression and mortality. $N$ Engl J Med. 351:23-32.

Ferencik, M., and Ebringer, L. (2003) Modulatory effects of selenium and zinc on the immune system. Folia Microbio/ 48:417-26.

Fleiger, D., Reithmuller, G., and Ziegler-Heitbrock, H. W. L. (1989) $\mathrm{Zn}^{2+}$ inhibits both tumor necrosis factor mediated DNA fragmentation and cytolysis. Int J Cancer 44:315-319.

Gomall, A. J. (1949). Biol. Chem 177 C 751.

Harakeh, S., Jariwall, R. J., and Pauling, L. (1990) Suppression of human immunodeficiency virus replication by ascorbate in chronically infected cells. Proc Natl Acad Sci USA 87:7245-9.

Jaruga, P., Jaruga, B., Gackowski, D., Olczak, A., Halota, W. and Pawlowska, M. (2002). Supplementation with antioxidant vitamins prevents oxidative modification of DNA in lymphocytes of HIV-infected patients. Free Radic Biol Med 32:414-420.

Jiamton, S., Pepin, J., Suttent, R., Filteau, S., Mahakkanukrauh, B., and Hanshaoworakul, W., Chaisilwattana, P., Suthipinittham, O., Shetty, P., and Jaffar, S. (2003). A randomized trial of the impact of multiple micronutrient supplementation on mortality among HIVinfected individuals living in Bangkok. AIDS 17:2461-2469.

Kenako, J. J. (1999). Clinical Biochem of Animal $4^{\text {th }}$ edition. (Ed) academic press Inc. New York P. 932.

Larsen, K. S., and Auld, D. S. (1991). Characterization of an inhibitory metal binding site in carboxypeptidases A. Biochemistry 30:26132618.

Meydani. S., Wu, D., Santos, M., and Hayek, M. (1995). Antioxidants and immune response in the aged: overview of present evidence. $A m \mathrm{~J}$ Clin Nutr 62(suppl):1462S-76S.
Mocchegiani, E., Muzzioli, M., and Gaetti, R. (1999). Contribution of zinc in reducing CD4+ risk factor for 'sever' infection relapse for aging: parallelism with HIV. Int J Immopharmacol 21:271-281.

Mocchegiani, E., Muzzioli, M., and Gaetti, R. (1999) Contribution of zinc in reducing $\mathrm{CD} 4+$ risk factor for 'sever' infection relapse for aging: parallelism with HIV. Int J Immopharmacol 21:271-281.

Mocchegiani, E., Scalise, G., and Veccia, S. (1992). Zinc dependent thymic hormone failure in AIDS. Ann. NY Acad Sci 650:94-98.

Ngondi, J. L., Oben, J., Etame, L. H., Forka, D. M. and Mbanya, D. (2006) The Effect of Different Combination Therapies on Oxidative Stress Markers in HIV Infected Patients in Cameroon. AIDS Res Ther. 3(1): 19.

Okhawa, H., Ohishi, N., and Yagi, K. (1979) Assay for lipid peroxidation in animal tissues by thiobarbituric acid reaction. Annals Biochemistry 95:351-358.

Packer, L. (1993). Inactivation of NF-kB activation by vitamin E derivatives. Biochem Biophys Res Commun 193:277- 83.

Packer, L., and Suzuki, Y. (1993). Vitamin E and alphalipoate: role in antioxidant recycling and activation of the NF-kB transcription factor. Mol Aspects Med 14:229 -39.

Papadopulos-Eleopulos, E. (1988). Reappraisal of AIDS. Is the oxidation induced by the risk factors the primary cause? Med. Hypotheses 25: $151-162$.

Papadopulos-Eleopulos, E., Hedland-Thomas, B., and Causer, D.A. (1989). An alternative explanation for the radiosensitization of AIDS patients. Int. J. Radiat. Oncol. Biol. Phys. 17: 695-696.

Pinnell, A. E., and Northam, B. E. (1978) Quantitative in vitro determination of albumin in serum and plasma. Clin Chem 24:80.

Roe, J. H., and Kuether, C. A. (1943). The determination of ascorbic acid in whole blood and urine through the 2, 4dinitrophenylhydrazine derivative of dehydroascorbate. J. Biol. Chem. 147:399.

Rousseau, M. C., Molines, C., Moreau, J., and Delmont, J. (2000). Influence of highly active antiretroviral therapy on micronutrient profiles in HIV-infected patients. Ann Nutr Metab 44:212-216.

Scrimshaw, N. S. and SanGiovanni, J. P. (1997). Synergism of nutrition, infection, and immunity: an overview. $A m J$ Clin Nutr 66(suppl):464S-77S.

Semba, R. D. (1999) Vitamin A and immunity to viral, bacterial and protozoan infections. Proc Nutr Soc 58:719-27.

Semba, R. D. and Tang A. M. (1999). Micronutrients and the pathogenesis of human immunodeficiency virus infection. $\mathrm{Br} J$ Nutr 81:181-189.

Spriestma, J. E. (1999) Cystein, glutathione (GSH) and zinc and copper ions together are effective, natural, intracellular inhibitors of (AIDS) viruses. Med Hypotheses 52:529-538. 
Tanaka, Y., Shiozawa, S. and Morimoto. I. (1990) Role of zinc in interleukin 2 (IL-2)-mediated T-cell activation. Scand J Immunol 31:547552.

Tang, A. M., Lanzilloti, J., Hendrieks, K., Gerrior, J., Ghosh, M., Woods, M. and Wanke, C. (2005) Micronutrients: Current Issues for HIV Care Providers. AIDS. 19 (9):849-862.
Tang, A. M., Smit, E, and Semba, R. D. (2000) Improved Antioxidant Status Among HIVInfected Injecting Drug Users on Potent Antiretroviral Therapy. J Acquir Immune Defic Syndr 23:321- 6.

Zhang, Z., Reardon, I. M., and Hui, J. O. (1991) Zinc inhibition of rennin and the protease from human immunodeficiency virus type 1 . Biochemistry 30:8717-8721.

\section{APPENDIXES}

\section{Appendix 1: Socio demographic distribution of all patients in the study [n (\%)]}

\begin{tabular}{ll} 
Variables & $\mathrm{n}(\%)$ \\
\hline Sex: male & $38(35.2)$ \\
female & $70(64.8)$ \\
Education Status: & $25(23.1)$ \\
no formal education & $13(12.0)$ \\
primary education & $40(37)$ \\
secondary education & $14(13)$ \\
undergraduate education & $16(14.8)$ \\
post graduate education & $61(56.5)$ \\
Economic status (Naira/month): & $17(15.7)$ \\
< 5 000 (<3.3USD) & $21(19.4)$ \\
$5000-9000$ (3.3-6USD) & $9(8.3)$ \\
10 000-35 000 (66.7-233.3USD) & \\
>35 000 (>233.3USD) & $23(21.3)$ \\
Marital Status: & $62(57.4)$ \\
single & $8(7.4)$ \\
married & $15(13.9)$ \\
divorced & \\
widowed &
\end{tabular}

Figure 1 presents different ARV combinations which patients under the study were placed on during the period of the study. The result shows that $25 \%$ of the patients were naive, $28.83 \%$ were on zidovudine (AZT), lamivudine (3TC) and nevirapine (NVP) combinations; $10.83 \%$ were on Truvada and NVP combinations; $7.5 \%$ were on AZT, 3TC and stavudine (d4T) combinations; $6.7 \%$ were on Truvada and efervirenz (EFV) combinations; $2.5 \%$ were on the combinations 3TC, d4T; $1.7 \%$ were on each of the combinations: NVP and 3TC, Truvada and 3TC, Truvada and Combivir, Truvada and Alluvia, and Truvada and Trimune; while $0.8 \%$ lives on each of the combinations: AZT, NVP and Truvada, NVP, 3TC and Telinum, NVP, EFV and Abakavir, NVP and d4T, 3TC and d4T, EFV and Combivir, EFV and Kaletra, Truvada and Kaletra, Truvada and Abakavir (ABC), AZT, d4T and NVP, and 3TC, d4T and EFV. This shows that majority of patients under the study (over 38\%) who are on ARV therapy, have AZT as part of their ARV combinations; and are on a wide range of ARV combinations.

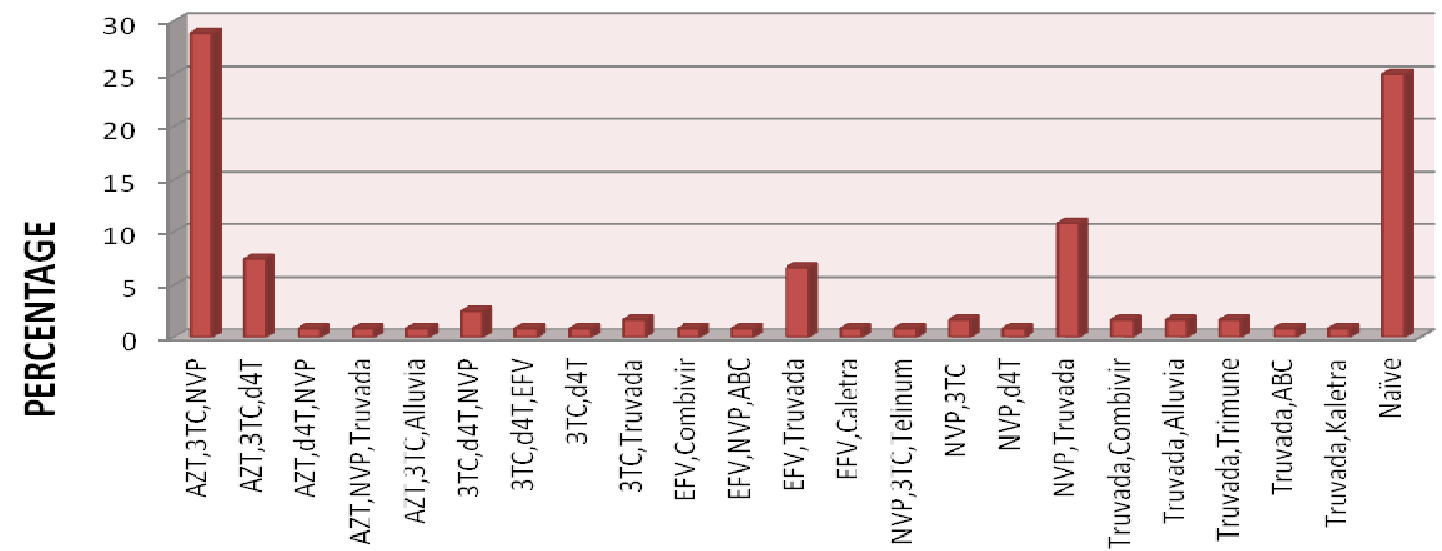

FIGURE 1. DISTRIBUTION OF SUBJECTS IN TERMS OF ANTIRETROVIRAL COMBINATIONS 
Bajopas Volume 9 Number 1 June, 2016



Mohd Mustapha Jibril

Amina Ohuneno

Catherine Ojemba Attal

Joshua Pius

Department of Biochemistry

Through:

The Head of Department

Department of Biochemistry

Bayero University Kano.

Kano.

RE: WTHICAL APPIROVAL

RE: EFIECTS OF MUCRONUTRIENTS AND HIGHLY ACTIVE ANTI

RETROVIRAL THERAPY (HAART) ON THE GENERAL OUTCOME OF HIVIAIDS IN IIV PATIENTS TAKING HAART IN AKTH

Refer to your application and the subsequent response on the above research proposal The Committee has considered your proposal and noted same as a prospective study.

In view of this, Ethical approval is hereby granted to conduct the research.

Jowever, the proposal is subject to periodic reporting of the progress of the study.

Best regards.

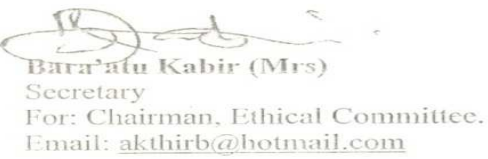

